\title{
EFFECT OF PRIMING ON GERMINATION AND INITIAL GROWTH OF MELON PLANTS UNDER SALT STRESS
}

\author{
Castañares, J. L. ${ }^{1} \&$ Bouzo, C. A. ${ }^{2}$
}

\begin{abstract}
The objective of this work was to evaluate the effect of different osmotic agents and priming durations on the germination and initial growth of melon in salinity. The osmotic agents were $\mathrm{NaCl}$ and $\mathrm{CaCl}_{2}$ and durations 2 and 4 days. First a response curve of germination to salinity was made. After priming the seeds were placed to germinate in a saline medium $\left(14 \mathrm{dS} \mathrm{m}^{-1}\right)$. The germination percentage was determined. The two treatments with the best results ( $\mathrm{NaCl}$ and $\mathrm{CaCl}_{2} 2$ days in both salts) were selected to evaluate the initial growth of the plants in salinity. It was sown in pots, irrigated with nutrient solution and $60 \mathrm{mM} \mathrm{NaCl}$. The germination was reduced to $50 \%$ with $14 \mathrm{dS} \mathrm{m}^{-1}$ and inhibited with $22 \mathrm{dS} \mathrm{m}^{-1}$. The best germination was achieved with $\mathrm{NaCl}$ and $\mathrm{CaCl}_{2} 2$ days with 99 and $94 \%$ respectively. Both treatments showed an increase in growth parameters and chlorophyll content.
\end{abstract}

Key words: priming, germination, salinity, stress.

\section{RESUMEN}

Efecto del priming en la germinación y crecimiento inicial de plantas de melón en estrés salino.

El objetivo del trabajo fue evaluar el efecto de diferentes agentes osmóticos y tiempos de priming en la germinación y crecimiento inicial de melón en salinidad. Los agentes osmóticos fueron $\mathrm{NaCl}$ y $\mathrm{CaCl}_{2}$ y los tiempos del tratamiento 2 y 4 días. Primeramente se confeccionó una curva de respuesta de la germinación a la salinidad. Luego del priming las semillas se colocaron a germinar en

2.- Departamento de Ciencias Básicas. Universidad Nacional de Luján. Rutas NAcionales 5 y 7. (6700) Luján provincia de Buenos Aires. Email: joseluis.cas@gmail.com

2.- Departamento de Producción Vegetal. Facultad de Ciencias Agrarias (UNL). (3080) Esperanza, provincia de Santa Fe... . .. . . . . . ......

Manuscrito recibido el 4 de julio de 2017 y aceptado para su publicación el 15 de septiembre de 2017. 


\section{J. L. Castañares et al.}

un medio salino $\left(14 \mathrm{dS} \mathrm{m}^{-1}\right)$. Se determinó el porcentaje de germinación. Se seleccionaron los dos

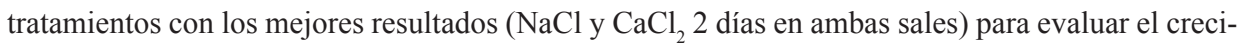
miento inicial de las plantas en salinidad. Se sembró en macetas, regándose con solución nutritiva y $60 \mathrm{mM}$ de $\mathrm{NaCl}$. La germinación se redujo al $50 \%$ con $14 \mathrm{dS} \mathrm{m}^{-1}$ y se inhibió a $22 \mathrm{dS} \mathrm{m}^{-1}$. La mejor germinación se logró con $\mathrm{NaCl}_{\text {y }} \mathrm{CaCl}_{2}$ a los 2 días con 99 y $94 \%$ respectivamente. Ambos tratamientos mostraron un incremento de los parámetros de crecimiento y clorofila.

Palabras clave: priming, germinación, salinidad, estrés.

\section{INTRODUCTION}

Soil salinity is one of the most important conditions for growing melon. Salinity can conduce to a reduction of percentage and germination rate $(6 ; 46)$. In addition, in severe salt stress conditions, the seedlings can show a reduction of aerial biomass (28), inhibition of stem, leaf and root growth (5), reduction of leaf water potential and stomatal conductance (29), metabolic alterations with photosynthesis decrease (14) and reduced fruit yield and quality $(32 ; 14)$. However, if development of plants is considered, germination and initial seedling growth phases have the highest sensitivity to salinity, increasing tolerance between fruit development and harvest $(37 ; 17 ; 9 ; 45)$. The technique of pre-conditioning seeds (priming) can become a technological alternative to overcome limitations imposed by salinity.

Priming is a controlled seed hydration technique that allows activating the metabolic and repair processes (activation of DNA repair pathways and antioxidant mechanisms) that occur in early stages of imbibition (pre-germinative metabolism), without radicle emission (germination) (38). Priming treatments have proven their advantages and are investigated for the following purposes: a) seed invigoration during storage; b) increase, acceleration and synchronization of germination and establishment of seedlings; c) overcoming or alleviation of different types of dormancy and; d) improvement of germination and establishment of seedlings under adverse environmental conditions $(25 ; 41)$.

Controlled hydration can be achieved with an osmotic agent that reduces the osmotic potential ( $\Psi 0$ ) of water (osmopriming), a substance that retains surface water (matric priming) or the addition of a limited amount of water (hydropriming) (49). Osmopriming is the main technique used because of simplicity and satisfactory results (22). The beneficial effects of priming are not exclusive of seed germination and can be can be extended to later stages by increasing tolerance to different biotic and abiotic stresses $(11 ; 13 ; 35)$.

The objective of this work was to evaluate the effect of different osmotic agents and priming durations on germination and initial growth of melon plants under salinity stress. 